\title{
FAMILY BUSINESS: AN ENTREPRENEURIAL LONGER-TERM PERSPECTIVE
}

\author{
Ratna L. Nugroho \\ Program Studi Magister Manajemen, Fakultas Ekonomi dan Bisnis, Universitas Telkom, \\ Jl.Gegerkalong Hilir No.47, Bandung, Jawa Barat, 40152, Indonesia \\ ratnalnugroho@telkomuniversity.ac.id
}

Received: 29 $9^{\text {th }}$ March 2016/ Revised: $13^{\text {rd }}$ April 2016/ Accepted: $19^{\text {th }}$ April 2016

How to Cite: Nugroho, R.L. (2016). Family Business: An Entrepreneurial Longer-Term Perspective.

Binus Business Review, 7(1), 9-16.

http://dx.doi.org/10.21512/bbr.v7i1.1428

\begin{abstract}
This family business case study is concerned with investigating the issue of the complexity of the many views of the family business research, focusing exclusively on the entrepreneurial concept. In taking this concept, three characteristics were identified, namely: the attitudes, the skills, and the behavior. Along with these findings, it is suggested that the conceptual model, the so-called "the three circles," where it has an overlap and identify as a longer-term entrepreneurial perspective within the family-owned enterprise.
\end{abstract}

Keywords: family business, entrepreneurial, competitive advantage, conceptual model

\section{INTRODUCTION}

The phrase "family business" connotes a small or mid-sized company with a local focus and a familiar set of problems, such as squabbles over succession. While plenty of mom-and-pop firms certainly fit that description, it doesn't reflect the powerful role that family-controlled enterprises play in the one nation's economy. Conventional wisdom holds that the unique ownership structure of family businesses gives them a long-term orientation that traditional firms often lack. However, beyond that, little known about exactly what makes family business different. Some studies suggest that, on average, they outperform other businesses over the long term, but other studies prove the opposite.

Poza (2007) argued that the importance of the existence of a family business in the world economy is reinforced by the data that $80 \%$ to $98 \%$ of business in the world is a family-controlled enterprise. In addition to that, family businesses created $64 \%$ of Gross Domestic Product (GDP) in the United States and estimated that those family businesses contributed to the creation of another country's GDP by $75 \%$. Not to mention that family-controlled enterprises hold more than $85 \%$ of workers around the world. Another study by Degadt (2010) reported that only $37 \%$ of 1,100 surveyed American family business had a written strategic plan. A similar survey among 154 Belgian family businesses yielded $45 \%$ positive answers against $67 \%$ for non-family businesses. The management of familyowned companies is often reluctant to put a strategic plan on paper because they are afraid that it can be used against them by their employees, customers, and suppliers. In addition to this, Degadt (2010) argued that family business is the companies that operate in a market economy. They need to be competitive, and they are subject to the same rules of the game as the other type of businesses. Meryana (2011) reported that in Asia the family-controlled enterprises recorded a cumulative total profit of $261 \%$ over the year of 2000 to 2010, with the compound annual growth rate of $13.7 \%$ during that decade. Based on the regional distribution, Southern Asia has a number of family businesses with the highest percentage of approximately $65 \%$ of the total listed companies. Meanwhile, Northern Asia is being the lowest with $37 \%$. By country, India is the owner of the largest number of family businesses with $67 \%$ of the listed company, while China became the lowest with $13 \%$. 
In the context of Indonesia, Chitania and Mustamu (2014) explained that family business plays an important role, not only in stimulating the economic growth, but also creating jobs for millions of Indonesian people and established the family business tend to be a future career option for some people. During good economic times, family-run companies don't earn as much money as companies with a dispersed ownership structure. However, when the economy slumps, family firms far outshine their peers and across business cycles, long-term financial performance was higher for family businesses than for non-family businesses.

However, as it is always the case, family members come and go. One one side, key issues in family business is the succession, while on the other side, maintain the sustainability of family business is not easy. According to Hall and Mattias (2008), only $30 \%$ of the family businesses were able to survive the transition between generations in the second generation, while only $12 \%$ were able to survive the third generation and only 3\% were able to develop the fourth generation and beyond. By emphasizing more entrepreneurship for the long-run success of the family business, Davis and Roberts (2014) pointed out; "Families that want to stay in business for generations don't have a choice but to encourage entrepreneurship in and out of their family company."

Over the past decade, minimal research findings have been offered on how to build the long-term entrepreneurial perspective in the context of foodbased family business in Bandung City, West Java Province. This present research is intended to help fill that gap, by proposing the business strategy concept that consists of a firm's competitive advantage to prepare its strategic position in the future marketplace. A qualitative research approach is used to explore a deeper holistic understanding of what is the condition of its longer-term entrepreneurial perspective.

P\&D - this name was adopted from Dutch words "Proviand \& Drank", literally defined as "Food and Drinks" - was established in September 2005 and owned by the Professional Chef (hereinafter stated as Chef-CX) and his family. This family-owned enterprise sells cakes and pastry, such as tiramisu and other western cakes, which is made by Chef-CX himself. Other than cakes, P\&D also sell Indonesian foods that made by Chef-CX's wife. In addition to this line of products, they also provide a set menu for events such as wedding party, birthday party, in-house training and so forth. P\&D has never been stopping to do the entrepreneurship and innovation concepts. This effort was shown by their new product, the socalled P\&D Pizza, the tasty pizza that baked in the homemade oven that Chef-CX made by himself. This home-made oven is being sold by Chef-CX since there are a lot of demands for this product.

Although P\&D remain focused on its core business, it also faced some troubles, such as no significant growth regarding revenues or even some ups and downs, which is believed would definitely have an impact on their long-term growth. To settle this circumstance, the P\&D's existing internal environment and external environment were tried to be understood and analyzed to develop the new opportunities as a way to build their bright future. This study seeks to gain insights into family businesses, understand the owners and identify their longer-term entrepreneurial perspective to their success, which is based on indepth interviews. The ten years experiences of the P\&D family business are trusted to provide valuable insight for other family businesses as they adapt their operations to cope with the ever-changing and increasingly complex business environment.

From the author's point of view and the variety of terms for entrepreneurship concept, it is acknowledged that it is important to provide the foundation and starting point for a series of further discussions. In a number of literature around the world, the exact definition of the entrepreneur, entrepreneurship, and entrepreneurial is unclear and even be viewed confusingly. The multidimensional benefits entrepreneurship provides to society need to be illuminated. In addition, there is a need for clarity on the definitions of the entrepreneur, entrepreneurship, and entrepreneurial. There are many other words often used as substitutes for entrepreneurship, such as enterprise, innovation, small business, growth companies, and so on. To fully capture and understand the entrepreneurship phenomenon, including the entrepreneur and the entrepreneurial, it is considered necessary and useful to elucidate the approach and illustration from the World Economic Forum (2009), as illustrated in Figure 1.

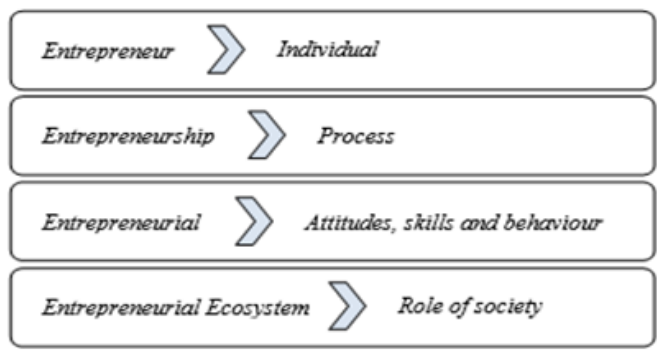

Figure 1 The Meaning of Entrepreneur, Entrepreneurship, Entrepreneurial and Entrepreneurial Ecosystem Source: World Economic Forum (2009) 
Entrepreneur is derived for the French verb "entreprendre" which means to undertake, to attempt, to try in hand, to contract for; or, to adventure; to try. Consequently, it should come as no surprise that the Webster's New World Dictionary defines the term as "one who organizes and manages a business and undertakes the risk for the sake of profit." As far as the author is concerned, currently, no single definition of "entrepreneur" has been uniformly accepted in the literature. Scholars and researchers continue to write about and examine characteristics and competencies describing entrepreneurs. Nixdorff (in Solomon, 2006) examined the literature and developed a table showing the wide diversity of competencies attributed to entrepreneurs to see if there were any commonalities in competencies across authors, as illustrated in Table 1 .

Table 1 Entrepreneurial Competencies from a Small Sample of Journal Articles

\begin{tabular}{|c|c|c|c|c|c|c|c|c|c|}
\hline \multirow[b]{2}{*}{ Competencies } & \multicolumn{9}{|c|}{ Authors } \\
\hline & $\begin{array}{l}\text { Bird, } \\
2002\end{array}$ & $\begin{array}{c}\text { Thompson, } \\
1999\end{array}$ & $\begin{array}{l}\text { Santi, } \\
1994\end{array}$ & $\begin{array}{l}\text { Fiet, } \\
2000\end{array}$ & $\begin{array}{c}\text { Hisrich, } \\
1992\end{array}$ & $\begin{array}{c}\text { Hood } \\
\text { et al, } \\
1993\end{array}$ & $\begin{array}{l}\text { Nieuwenhuizen } \\
\text { et al, } 2002\end{array}$ & $\begin{array}{c}\text { Vesper } \\
\text { et al, } \\
1988\end{array}$ & $\begin{array}{c}\text { Ronstadt, } \\
1985\end{array}$ \\
\hline Achievement/task motivation & $\mathrm{X}$ & $\mathrm{X}$ & & & & & $\mathrm{X}$ & & \\
\hline Change-oriented & & & & & $\mathrm{X}$ & & & & \\
\hline Create \& utilize networks & $\mathrm{X}$ & $\mathrm{X}$ & & & & & & & $\mathrm{X}$ \\
\hline Create capital & & $\mathrm{X}$ & & & & & & & \\
\hline Creativity/Idea generation & $\mathrm{X}$ & $\mathrm{X}$ & & $\mathrm{X}$ & $\mathrm{X}$ & $\mathrm{X}$ & $\mathrm{X}$ & $\mathrm{X}$ & $\mathrm{X}$ \\
\hline Decision making/evaluation & & & & & $\mathrm{X}$ & $\mathrm{X}$ & & & $\mathrm{X}$ \\
\hline Design business organization & $\mathrm{X}$ & & & & & & & & \\
\hline Design products or services & $\mathrm{X}$ & $\mathrm{X}$ & & & & & & & \\
\hline Discipline/Drive & $\mathrm{X}$ & & & & $\mathrm{X}$ & & & & \\
\hline Functional & $\mathrm{X}$ & & & & $\mathrm{X}$ & $\mathrm{X}$ & $\mathrm{X}$ & $\mathrm{X}$ & \\
\hline Interpersonal skills & $\mathrm{X}$ & $\mathrm{X}$ & & & & $\mathrm{X}$ & $\mathrm{X}$ & & \\
\hline Leadership & $\mathrm{X}$ & & $\mathrm{X}$ & $\mathrm{X}$ & & & & & \\
\hline Listening & & & & & & & & $\mathrm{X}$ & \\
\hline Manage growth & & & & & & $\mathrm{X}$ & & & \\
\hline Manage project & & & $\mathrm{X}$ & & & & & & \\
\hline Manage risk & & $\mathrm{X}$ & & $\mathrm{X}$ & $\mathrm{X}$ & & $\mathrm{X}$ & & \\
\hline Maneuver in industry & $\mathrm{X}$ & & & & & & $\mathrm{X}$ & & \\
\hline Monitor the work of others & $X$ & & & & & & & & \\
\hline Motivate organizational members & $\mathrm{X}$ & & & & & & & & \\
\hline $\begin{array}{l}\text { Need for control of financial } \\
\text { outcomes }\end{array}$ & $X$ & & & & & & $\mathrm{X}$ & & \\
\hline Negotiation & & & & & $\mathrm{X}$ & & & $\mathrm{X}$ & $\mathrm{X}$ \\
\hline Opportunity recognition & & $\mathrm{X}$ & $\mathrm{X}$ & & & $\mathrm{X}$ & & $\mathrm{X}$ & $\mathrm{X}$ \\
\hline Oral communication & $\mathrm{X}$ & & & & & $\mathrm{X}$ & & $\mathrm{X}$ & \\
\hline Reality testing & & & & & & & & & $\mathrm{X}$ \\
\hline Resource finding/financing & & $\mathrm{X}$ & & $X$ & & & & & \\
\hline Planning, comprehensive & $\mathrm{X}$ & & & & & $\mathrm{X}$ & & & $\mathrm{X}$ \\
\hline Plan strategy & & & $\mathrm{X}$ & $\mathrm{X}$ & & & $\mathrm{X}$ & & $\mathrm{X}$ \\
\hline Technology & & & & & & & & $\mathrm{X}$ & \\
\hline Tolerance for ambiguity & $\mathrm{X}$ & & & & $\mathrm{X}$ & & & & $\mathrm{X}$ \\
\hline Vision & & & & & $\mathrm{X}$ & & & & \\
\hline Writing & & & & & & & & $\mathrm{X}$ & \\
\hline Ethics & & & & & & $\mathrm{X}$ & & & $\mathrm{X}$ \\
\hline
\end{tabular}

Source: Nixdorff (in Solomon, 2006)

Back in the 1960s, David McClelland developed his three-factor theory of motivation and expanded his research by examining achievement motivation and economic development and the role of the entrepreneur. His research builds upon the work of Schumpeter (1934) but focused primarily on how to train individuals to be more achievement oriented thus becoming entrepreneurial. In short, McClelland's research examined achievement motivation and its effect on individual's desire to start and manage a new venture. His later research showed some causality between a highly achievement motivated individual and economic growth.

Given the complexity of the many views of the entrepreneur, entrepreneurship and entrepreneurial concept associated with this case study, it is important to the reader to understand the relevance of the entrepreneurial concept to the topic of family business. Therefore, with the help of illustration in Figure 1 and the entrepreneurial competencies in Table 1 as well as 
for the purpose of this family business case study, the following definition of "longer-term entrepreneurial perspective" is proposed:

Entrepreneurial longer-term perspective represents the attitudes, skills and behavior which focus on the pursuit of the future opportunities in order to nurture talent and develop the next generation of family-owned business managers and innovators who will solve the complex, interlinked and fast-changing problems.

How to define a family-owned enterprise remains problematic in family business research. Although many researchers have tried to develop a satisfactory definition, there is still no consensus about widely accepted definition. Although some studies in the finance literature identify any public company where a family or founder owns more than $5 \%$ as a family-owned enterprise, other studies define enterprise only as family enterprise if the first succession into the second generation has taken place. However, in most studies a family-owned enterprise has been characterized as an enterprise that is controlled and usually managed by multiple family members, sometimes from multiple generations.

The use of different definitions is a major problem in family business research. Although studies analyze related topics, the use of different familyowned enterprise definitions makes the comparability of these results difficult. One of the biggest challenges of developing a general definition is the heterogeneity of family-owned enterprise. Family businesses are a unique group of organizations, but they also differ within this group. The involvement of the family in the management and ownership structure of the enterprise is unique to each family business, and thus, it cannot be seen as a constant factor.

Numerous attempts have been made to articulate a conceptual and operational definition of family business. Various scholars have reviewed existing definitions, made attempts at consolidation of thoughts, and conceptualized another definition of the family business (e.g., Chua, Chrisman, \& Sharma, 1999; Handler, 1989; Litz, 1995). The focus of most of these efforts has been on defining family business so that they can be distinguished from non-family businesses. Although none of these articulations has yet gained widespread acceptance, most seem to revolve around the important role of family in terms of determining the vision and control mechanisms used in the enterprise, and creation of unique resources and capabilities (e.g., Chrisman, Chua, \& Litz, 2003; Habbershon, Williams, \& MacMillan, 2003).

For the purpose of this study, the essence approach by Chua, Chrisman, and Sharma (1999) was being followed in defining a family-owned enterprise as "a business governed and/or managed with the intention to shape and pursue the vision of the business held by a dominant coalition controlled by members of the same family or a small number of families in a manner that is potentially sustainable across generations of the family or families".

\section{METHODS}

Drawing on examples from the author's published qualitative research and the complementary insights from other case study work in the field of entrepreneurship studies (e.g., Lubis, 2013; Lubis, 2014, Nugroho, 2015), the case study approach design is chosen to generate the new and valuable insights in the family business field. Other than that, this study attempts to move the family business field beyond its current state, encourages scholars to engage in the case study approach in high-quality family business research, and suggests important implications for scholars of case studies in the entrepreneurship, particularly in the family business field. Nonetheless, it is worth noted to explain that although the case study approaches have contributed to the intuitive understanding of the nature of a family business, such approaches are limiting in terms of generalizability.

It was noted that the previous sampling methods on family business studies are derived in a variety of ways. For example, some researchers have used databases that represent a variety of industries, other researchers have used business sampling frames with minimum annual revenues and ownership criteria, some searchers have chosen specific professions to target, other researchers have used clientele lists from professional firms or lists from state chambers of commerce, newsletter and/or family business associations, or specialized yellow pages (Winter et al., 1998). Meanwhile, other researchers argued that the field of family business research will need to develop and innovate by expanding its conceptual boundaries to more reflectively appreciate the past, open its international boundaries to welcome findings from a growing array of international and ethnic contexts, and enrich its inherent complexity to appreciate works that present novel variables and engage an increasingly diverse set of topics (Litz, Pearson, \& Litchfield, 2012).

Given the complexity of the many views of the family business research methodology, it was acknowledged that the case studies approach on P\&D in their natural settings and collect the variety of empirical materials, such as personal experience, life story, observational, semi-structured interviews, visual texts, as well as introspective; will contribute to the emerging domain of family business research. From this point, it has been chosen that the husband, wife and the daughter who owned the P\&D that represents the household-based sample of business which may provide great insights and greater detail into the nature of business and family. It should be noted here that the husband refers to as "Respondent-1 or R1", the wife refer to as "Respondent-2 or R2" and the daughter refers to as "Respondent-3 or R3". Aside from those 
two respondents, the empirical materials from nonfamily members in P\&D, such as the kitchen head, is also collected.

In order to illustrate the entrepreneurial longterm perspective from the owner of $\mathrm{P} \& \mathrm{D}$, therefore the guidance of the following three essential research questions is being followed: (1) how does the P\&D's owner manage their resources to develop the potential business opportunities to grow their family-owned enterprise? (2) How does the P\&D's owner identify their possible competitive advantage to support their existing products and services? (3) How does the P\&D's owner manage their resources to gain their future competitive advantage?

\section{RESULTS AND DISCUSSIONS}

In this section, the results of the case study approach design will be presented systematically based on the above mentioned three essential questions. Data reduction treatment included the following process: semi-structured interview, observation as well as documentation. Since this research is approached from the standpoint of the business owner in their natural settings, therefore the findings have to be interpreted as a dynamic process of meanings in the making, rather than static meaning, which may offer wider insights to uncover a greater understanding of the family business field.

Based on the semi-structured interview to R1, $\mathrm{R} 2$ and R3 as well as the kitchen head, it was found that in terms of the job and responsibilities they all come to an agreement that there is actually not much difference between them. In short, there is equal treatment of responsibilities between the family member and the non-family member to develop potential business opportunities for P\&D. According to R1 and R2, even though the ownership and operation management of P\&D has been handled by them, nonetheless there are also some distant-related family members who play their role as a cashier, a driver, or the staffs in the administration department.

In addition to this condition, R1 and R2 further clearly stated that they do care about the togetherness; therefore, everything about the business must be on the basis of fairness. Also, no matter how high the position of the family member in $\mathrm{P} \& \mathrm{D}$ organization structure, in the context of professionalism, the one at the top would never do favoritism. R1 do believe that favoritism could potentially create a problem for a non-family member, which could lead to sabotage of the business. In short, the owner of P\&D has been trying to avoid this kind of problem.

In terms of human capital, it was found that R3 indirectly learns from the daily operational, such as the process of making the cakes and pastries, the process of serving the customers, and the way her parents dealing with the daily problems. This condition illustrates how the family member of P\&D builds their own tacit knowledge from the daily observation which may also lead to a strong commitment to developing the potential business opportunities.

In terms of tacit knowledge, $\mathrm{R} 1$ and $\mathrm{R} 2$ explained that they often enjoy their competitive advantage in the form of trustworthy relationship with non-family members, such as kitchen head, driver and cashier. In addition to this, R3 further explained that there is a certain assured feeling for her since she is a daughter of the P\&D owner, therefore, she feel an enjoyment to learn the tacit knowledge from her parents on how to run the cake and pastry business.

In terms of social capital, R1 and R2 clearly stated that it is easier to transfer the knowledge and the important information among the family members. They do believe that the integration of knowledge inside P\&D is very important for them. Similarly, R2 also agreed to this condition and further explained that there is such emotional bonding among the family members that makes them closer to each other which may lead to developing the potential business opportunities for the future of P\&D.

Based on the daily observation during this study, it was found that $\mathrm{P} \& \mathrm{D}$ can provide the unique professional work experiences for their employees, both for the family members and non-family members. For example, the kitchen head told that although he is not the family member, he feel that he learns a lot of new knowledge from R1 and R2. He also added that the culture in $\mathrm{P} \& \mathrm{D}$ totally different with the previous family-owned business that he worked with for around 5 years. These differ in terms of the financial stability and a favorable working environment in P\&D. Another example in the context of professional experience was told by R3. Although she felt that she is quite young to run the daily operation of $\mathrm{P} \& \mathrm{D}$, she believes that her parents trust her to do the work and she doubted that this condition would be available for her in another pastry business.

It was found that both R1 and R2 agreed to the concept of the employee's welfare and, therefore, they put the employee's welfare as one of their missions. R1 explained very clearly that he and her wife always try to create the comfortable working environment to their employees, where everyone is treated as part of the family in P\&D. Such treatment was shown by the daily food they give to all the employees and a place to live for those who come from outside the city. It was observed that the working environment in P\&D could be seen as emotionally and financially satisfying, which may lead to the quality of human resources and the source of competitive advantage for $\mathrm{P} \& \mathrm{D}$ future. In short, the $\mathrm{P} \& \mathrm{D}$ has the intertwining between family and a non-family member which may identify as the possible competitive advantage.

In addition to this condition, $\mathrm{R} 1$ also stated that having been involved in the pastry business for about a decade, his family welfare is increasing from year to year. His family also has a good reputation from their external environment since $P \& D$ put the quality as one of their values. R1 and R2 explained that other values that make them exist along those ten years are trustworthy, which lead to the loyalty and a good 
relationship between family and non-family members. Moreover, R1 and R2 added on their interview session that their unique cake and pastry products are one of the pioneers in the city and Chef-CX was known as the famous chef in the city. This condition is another possible competitive advantage from existing internal condition and would be difficult to imitate by the other competitors. In other words, the uniqueness of $P \& D$ in terms of products and the owner reputation may also identify as the entrepreneurial longer-term perspective to the future of the family-owned enterprise.

R1 and R2 not only share their cake and pastry business knowledge to their non-family members, they also conduct the cooking class. This cooking class is open to all who interested in making pizza, cake or pastry. For example, R1 and R2 run the kids' cooking class for the elementary schools students, the cooking class for the retired employees and the cooking class as part of the human resources program from one of the banking industry in the city. By doing so, P\&D was seen as the family-owned business that "walk the talk" since the statement of "to keep sharing our business knowledge" is one of the P\&D mission statement. In other words, the owner of P\&D was able to identify their possible competitive advantage and may also identify as the entrepreneurial longer-term perspective to the future of the family-owned enterprise.

Resources orchestration is concerned with the top management actions to facilitate efforts by being effectively manage the firm's resources. It was found that R1 clearly stated that all the internal human resources in $\mathrm{P} \& \mathrm{D}$ use all the resources as the most optimal way as they could. Their main concept of using the resources is illustrated with the following statement; "Any good resources could be better resources, and any bad resources could also be good resources".

Along with this statement, it was also found that the way they acquire their resources are well managed. R1 added in his interview session, that they take into consideration the opportunities and threats within the external environment. They always try to take any possible advantages of all the resources they have, which lead to specific ways in producing a good quality cake and pastry. Meanwhile, R1 explained that they have no difficulties to make an investment and also have no difficulties to bear the longer time in return. Having realized that situation, they are able to leverage their resources more efficiently since they have a long-term orientation. They may even invite the non-family members, such as their friends for investing in the lower-return project. Such advantage is likely to be associated with greater long-term economic value creation by $\mathrm{P} \& \mathrm{D}$. In short, it should be noted that the family-owned enterprise such as $\mathrm{P} \& \mathrm{D}$ has a unique way to raise their capital.

Similarly to this condition, it was found that the family members in P\&D work on the voluntary basis to run the daily operation. The combination of investment concept and the voluntary human capital creates a survival mode to $\mathrm{P} \& \mathrm{D}$ which leads to the longer-term future growth. In creating the socioemotional wealth, both R1 and R2 explained that even though their family-owned business consistently prioritizes the financial aspects, however, the nonfinancial aspects also have a high priority for them to grow their business. For example, R1 stated that the feeling of independent among family members is highly important since he wants to prepare the path for $\mathrm{P} \& \mathrm{D}$ next generation. R2 explained that all the family members always happy to make pastries, cakes, and other western cookies. R2 also explained that making pastries and cakes is one of their hobbies and they passionately distribute their knowledge to others in order to create a happy culture for $\mathrm{P} \& \mathrm{D}$ future to fulfill the socio-emotional needs of P\&D employees. It was observed that what R2 explained in her interview session was actually showed when she made all the pastries in the kitchen.

$\mathrm{R} 1$ as the head of the family does not hesitate to point out that his family business is not a charity. $\mathrm{He}$ recalls his earlier years during the economic downturn when his mother told him "sedia payung sebelum hujan" which literally means that "savings will guarantee to keep someone moving on". As an owner of P\&D, Chef-CX explained that he will continue to apply his mother lesson to gain the P\&D's future competitive advantage. "We have a simple rule, we do not spend more than we earn", R1 told the author. But on the other hand, in the context of unforeseeable future, it was noted that R1 also expressed his concerned about the succession issues as the greatest challenges.

Up to this point, it was witnessed that $P \& D$ is one of a good example of a family-owned enterprise that was able to leverage their entrepreneurial longerterm perspective in creating competitive and longterm sustainability. Starting the business a decade ago in 2005, the husband and wife tapped into both the direct family and non-family labor pool and capital pool to get the business off the ground. The loyalty demonstrated by both the family and nonfamily members during those start-up years was instrumental in keeping their entrepreneurial longerterm perspective alive. Although P\&D is still a young cake and pastry shop, P\&D's owner are now starting to think about creating a legacy.

As noted from the abovementioned findings on how all the respondents explained the potential business opportunities, the possible competitive advantage to support the existing internal condition and the effort to manage the resources to gain the future competitive advantage, perhaps the next question is "What then might be ahead for P\&D?" The answer to these questions appears largely dependent on how the owner sees the present.

To settle this condition, it is suggested that the conceptual model, the so-called "The three circles", where these three circle has an overlap and identify as an entrepreneurial longer-term perspective within the family-owned enterprise. The idea of "The three circles" was developed based on the findings from the semi-structured interview, observation as well as 
documentation. The owner of family business hopefully could reach success if they have identified their unique circles. First, the owners must ask themselves what is the "Potential Business Opportunities or PBO". This might be the never ending internal and external analysis, or selling a unique product. Next, there should be a frank assessment of what might be the "Possible Competitive Advantage or PCA" based on the realistically can and cannot be. Finally, there needs to be a determination of what drives the "Future Competitive Advantage or FCA", that is, an identification of the relevant where it is rooted. The suggested conceptual model of "The three circles" for the future analysis of an entrepreneurial longer-term perspective in the family business field is presented in Figure 2.

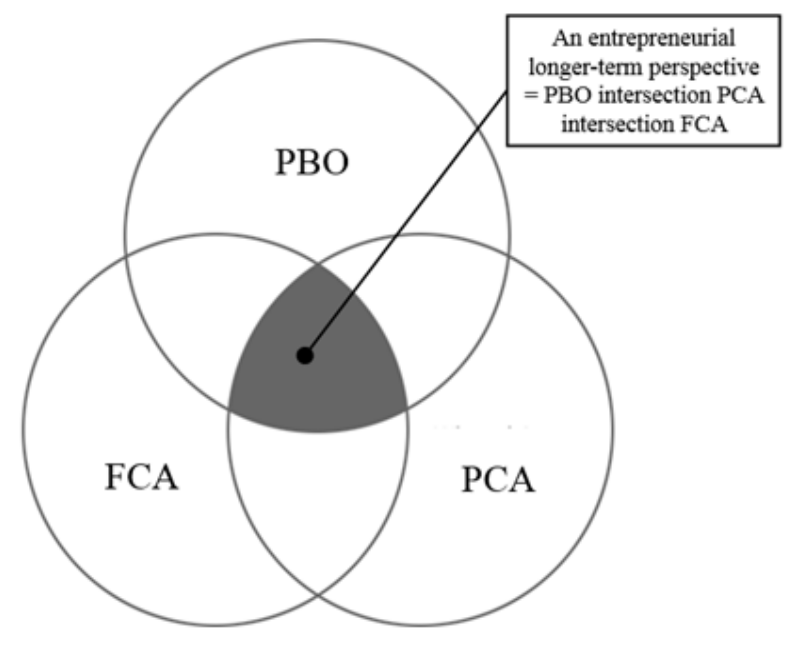

Figure 2 "The Three Circles" Conceptual Model (Authors' construct)

\section{CONCLUSIONS}

This family business case study is concerned with investigating the issue of the complexity of the many views of the family business research, focusing exclusively on the entrepreneurial concept. In taking this concept, three characteristics were identified in this P\&D case study, namely: (1) the attitudes, all respondents tend to pursue a good relationship as an organic growth of the business. (2) The skills, all respondents see the business know-how as the knowledge to share with others, not only within the internal organization but also for the external organization. (3) The behavior, all respondents have a lot in common with a collective mindset that helps them achieve goals.

All those three characteristics can be useful in guiding future research in the family business with particular emphasis on entrepreneurial longerterm perspective. While this present research has its limitations and is not intended to be the definitive literature on family business, it is hoped that "the three circles" at least offers a useful piece to the ongoing discussion as regard to the puzzle of family businesses' long-run success. In closing, one thing is for sure, the owner of the family business will need to learn that when it comes to company matters, it's not personal anymore, it's strictly business.

\section{REFERENCES}

Chitania, I., \& Mustamu, R. H. (2014). Perencanaan Suksesi pada Perusahaan Keluarga di Bidang Polyurethane Foam. AGORA, 2(1). Retrieved August 12, 2015, from http://studentjournal.petra.ac.id/index.php/ manajemen-bisnis/article/download/1518/1371

Chrisman, J. J., Chua, J. H., \& Litz, R. A. (2003). A unified perspective of family firm performance: An extension and integration. Journal of Business Venturing, 18(4), 467-472.

Chua, J. H., Chrisman, J. J., \& Sharma, P. (1999). Defining the family business by behavior. Entrepreneurship Theory and Practice, 23(4), 19-39.

Davis, J. A., \& Roberts, M. J. (2014). Managing the Family Business: Entrepreneurs Needed for Long-Run Success. Retrieved March 9, 2016, from http:// hbswk.hbs.edu/item/managing-the-family-businessentrepreneurs-needed-for-long-run-success.

Degadt, J. (2010). Strategic Entrepreneurship in Family Business - Experience from Belgium. Retrieved September 12, 2015 from https://lirias.kuleuven.be/ bitstream/123456789/408128/1/Rencontres 2010 Topic_A_Degadt_f.pdf

Habbershon, T. G., Williams, M. L., \& MacMillan, I. (2003). A unified systems perspective of family firm performance. Journal of Business Venturing, 18(4), 451-465. 
Hall, A., Mattias, N. (2008). Professional management in family business: Toward an extended understanding. Family Business Review, 21(1), 51-69.

Handler, W. C. 1989. Methodological issues and considerations in studying family businesses. Family Business Review, 2(3), 257-276.

Litz, R. A. 1995. The family business: Toward definitional clarity. Retrieved August 12, 2015 from http:// proceedings.aom.org/content/1995/1/100.full. pdf + html

Litz, R. A., Pearson, A. W., \& Litchfield, S. (2012). Charting the Future of Family Business Research: Perspectives From the Field. Family Business Review, 25(1), 16-32.

Lubis, R. L. (2013). Green "E-Project": The 4-R Survey of Students' Ecopreneurship. International Journal of Arts \& Sciences, 6(3), 181-197.

Lubis, R. L. 2014. Students' Entrepreneurial Strategy: Connecting Minds? International Journal of Arts \& Sciences, 7(3), 545-568.

Meryana, E. 2011. Bisnis Keluarga, Pilar Penting Perekonomian Asia. Retrieved August 12, 2015 from http://bisniskeuangan.kompas.com/ $\mathrm{read} / 2011 / 10 / 31 / 13565976 /$

Nugroho, R. L. (2015). Public Engagement through Ecopreneurship: Moving from 'Recyclable to
Marketable'. Procedia - Social and Behavioral Sciences, 184(5), 223-231.

Poza, E. J. (2007). Family Business, Second Edition. USA: South Western. Retrieved August 12, 2015 from http://forfreeshare.weebly.com/ uploads/1/2/5/1/12515971/family_business.pdf

Solomon, G. T. (2006). USASBE White Paper Series: Are We Teaching Small Business Management to Entrepreneurs And Entrepreneurship to Small Business Managers? Retrieved October 12, 2015 from http://www.google.com/ search?hl=en\&sugexp=kjrmc\&cp=39\&gs $\mathrm{id}=3 \mathrm{t} \& \mathrm{xhr}=\mathrm{t} \& \mathrm{q}=\mathrm{bab}$ on $\% 20 \mathrm{college} \% 2 \overline{0}$ entrepreneurship \% 20 concept \& g s $\mathrm{sm}=\& \mathrm{gs} \_u p l=\& b a v=o n .2$, or.r_gc.r_pw.,cf. $\mathrm{sb} \& \mathrm{biw}=1280 \& \mathrm{bih}=581 \& \mathrm{um}=1 \& \mathrm{ie}=\mathrm{UTF}-$ $8 \& \mathrm{sa}=\mathrm{N} \& \mathrm{tab}=\mathrm{iw}$

Winter, M., Fitzgerald, M. A., Heck, R. K. Z., Haynes, G. W., \& Danes, S. M. (1998). Revisiting the Study of Family Businesses: Methodological Challenges, Dilemmas, and Alternative Approaches. Family Business Review, 11 (3), 239-251.

World Economic Forum. (2009). Educating the next Wave of Entrepreneurs: Unlocking entrepreneurial capabilities to meet the global challenges of the $21^{\text {st }}$ Century. World Economic Forum: Switzerland. 